\title{
INTELLECTUAL [DIS]HONESTY IN ARCHITECTURE
}

\author{
Kenneth G. MASDEN II ${ }^{a}$, Nikos A. SALINGAROS ${ }^{b}$ \\ ${ }^{a}$ Department of Education, State of Hawaii, Honolulu, 96821 Hawaii, USA \\ ${ }^{\mathrm{b}}$ Department of Mathematics, University of Texas at San Antonio, San Antonio, 78249 Texas, USA

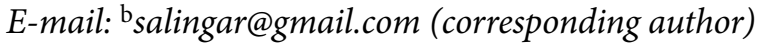

Received 18 April 2014; accepted 01 July 2014

\begin{abstract}
Many, if not a majority, of the world's citizens view contemporary architecture as ineffective in accommodating the lives of everyday human beings. And yet, voluminous texts by prominent architects and the media argue just the opposite; that, in fact, flashy and expensive new projects profoundly benefit humanity. Those buildings supposedly provide continued advancement in how humans occupy the world. While there is no doubt that the built environment is instrumental to human achievement and wellbeing, what is the true value of the ill-formed, and perhaps ill-conceived, products of today's leading architects? This essay argues that the elite power structure behind high-profile architectural projects is focused more upon promoting like-minded architects, and their narrow ideological interests, than in satisfying the ordinary everyday user. In doing so, this activity irrevocably damages the environment and markedly diminishes human neuro-physiological engagement with the man-made world. The logical conclusion from this purposeful misrepresentation is that the profession deliberately manipulates both the general public and architecture students to serve its own agenda.
\end{abstract}

Keywords: architecture, ideology, architectural education, cults, starchitects, power structures, intellectual dishonesty, Bauhaus.

\section{Introduction: architecture's purpose}

The discipline of architecture today has a somewhat dubious reputation among other disciplines - as a field wherein self-validating criteria perpetuate arguments of self-importance. This practice has long since been reified through repurposing the early slogan "art for art's sake" into "architecture for architecture's sake". Most Modern architects have been trained in this paradigm, and many take this edict to its extreme by completely denouncing program, function, purpose, and site (i.e. all practical measures of the built environment) in the pursuit of purist unencumbered architectural expressions (Salingaros, Masden 2010). The unconventional and unnatural forms embodying this ideological construct are often considered sacrosanct, so much so that architectural academia, today's design industry, and Western media zealously defend these architectural manifestations as unquestionable and exalted, if not divine (Mehaffy, Salingaros 2002).
Unfortunately, these aberrations of fashionable architecture are so unusual that many are fooled into believing that what they are seeing is a genuine advancement in architectural thinking. Unnatural in appearance as these modern buildings might be, images of such architecture progressively circulate the globe, establishing, legitimizing, and forging what may best be described as an esoteric (almost cryptic) language of design. As a result, the obscure ideas that accompany these forms have been easily institutionalized in the modern education of young architects without question or debate. To support this purely aesthetic ideology, the institution of architectural education has spent the past several decades insulating itself by way of its own internalized valuing system (Salingaros 2002). This intellectual isolation has bred an exclusive community of designers who would rather pursue a purely aesthetic expression of the built world than ever consider any practical measure or intelligent solution that the natural world might offer. 


\section{Architectural education}

By removing genuine, real-world architectural knowledge from the architecture curriculum, academics are better able to propagate their baseless theories, and readily indoctrinate students into their own peculiar ideologies. To support this shift in thinking, architecture schools that were originally a part of the College of Engineering had to distance themselves from all measures of applied science and the scrutiny of more practically-minded people. Once free of scientific thinking they either joined the College of Art, or became administratively independent altogether. Since they were no longer held to the course structure of schools teaching applied science, it became very easy to debase the intellectual level and course content.

The next step was to cull potential students with selective entry processes that drove the practical students away from architecture and into the sciences and engineering, while attracting those students who would rather invent without consequence or limit than seek to understand the real workings of architecture and the natural world. The freedom inherent in this educational model, while providing a place for the unconventional or unstructured thinking of many modern design students, also attracts challenged or somewhat dysfunctional students. By ostensibly promising four years of arts and crafts cloaked with the mystique of someday becoming an exalted contemporary architect, this learning environment fortifies the "artist against the world" (i.e. tortured soul) syndrome that many students assume over the course of their architectural studies.

Add to this the impossible tasks that students are regularly given, which often require that they stay up working all night, and you have the makings of a truly effective environment for brainwashing. The selective entry and purposefully difficult project requirements creates a sense of "initiation" that satisfies young students psychologically, making them think they are really accomplishing something. Through this experience, erroneously termed "design rigor", students can easily become convinced that what they are doing is truly important, valid, and real. The lack of sleep that such exercises demand enables the process of psychological conditioning and thus perpetuates the deception of dysfunctional design methods. This process is further reinforced by the architectural media's celebration of starchitects and their buildings made of everlasting shiny titanium panels.

\section{The starchitects' aims}

This hoax, which has befallen the modern world of design, has at its core a self-validating ideology of su- perficiality (i.e. image-based) and pseudo-intellectualism. We believe this model of design to be unintelligent, unsustainable, unscrupulous, and ill-conceived. We also believe that, with time, this artificial process will ultimately reach its own (un)natural limit. Our concern is what might occur in the vacuum created when the current system of beliefs collapses from its own irrelevance. Thus it is imperative that we begin a conversation with today's students to help demystify the architectural establishment's self-serving support for the current crop of starchitects. Students need to understand that many of today's prize-winning architects are compelled toward their own fame and personal profits, and are apparently willing to create a twisted world for everyone else to live in just to achieve their goal. This includes writing nonsensical texts and talking nonsense to justify their otherwise absurd buildings (Mehaffy, Salingaros 2011).

If these buildings were fine for human use, then it wouldn't matter what the architect uttered. Unfortunately, many contemporary "showcase" buildings are so dysfunctional and ill-conceived that they require an extensive narrative to defend their very existence. We not only blame these starchitects for their work - but equally the clients who knowingly commissioned it. There is certainly something ethically, if not morally, wrong with selling a defective product, even if that is permitted in the amoral view of how capital markets work. Architecture students and young designers should understand that users will eventually outgrow their dependency on image-based designs, realize the deception, and stop commissioning non-adaptive buildings (it hasn't happened yet, but there is ample reason to believe it is on the near horizon).

What is alarming is that this intellectual dishonesty begins at the very top of the profession - with some of today's most famous architects - and permeates without resistance down into the supposedly hallowed halls of architectural academia. Lacking a solid rational basis as a discipline, architecture is exposed to the personal whims and political ambitions of its key players. These power games define the system's intellectual elite and prescribe its misguided logic. We refer to this condition as "the politics of architectural discourse". There is purposefully no system of checks and balances, such as occurs in disciplines with a solid knowledge base like the sciences.

Thus, any famous architect who wields influence in the system can help situate a colleague as dean of a prestigious university, simply to further his or her own ideals (i.e. fame). All the while, this cronyism erodes and perverts the very nature of architectural design in the name of a few personal expressions. While such 
expressionism in the art world was thought to contain the higher sense of existentialism (i.e. the truest unmediated expression of one human in contact with the world), for architecture this practice is as unpractical as it is unhealthy. Incredibly, in today's architectural thinking, a conflict with the client is seen as a success for the architect, in that the purity of the architectural expression did not bow down to what modern architects consider the subjective whim of the client. Architecture needs to explore that which has never been, but there is a greater need to understand and support an architecture built through time and purpose to create the best places for humans to live.

\section{"Theory" that jettisons inherited knowledge}

Academic scientific departments themselves are not devoid of politics, yet the core body of scientific knowledge survives those conflicts, and is effectively transmitted to the younger generation. Architecture removed this guarantee when early modernist ideologues, such as the Bauhaus, scrapped the discipline's inherited knowledge, relegating the study of historic forms of architecture to the Fine Arts. The teachers of this new modernist ideology then took over both architectural education and practice worldwide, resulting in their resounding personal success at the expense of the entire discipline.

Overturning architecture's prior dependence on the natural aspects of materials and methods, formalistic arguments were substituted in place of direct observation. The Bauhaus, for example, studiously developed design techniques that REMOVED natural geometrical qualities from built structures. While Bauhaus readings might suggest that their design philosophy stemmed directly from nature as a source of design inspiration, the unnatural quality of their designs belies any such claims (Mehaffy, Salingaros 2002). Within the paradigm of this Machine-Age Design (MAD) thinking, instituted by the Bauhaus teachers, new ways of teaching and evaluating the work of architecture students and practitioners created the basis for what was to come - a descent into self-congratulatory sycophancy.

Architectural academics have long utilized other such clever ploys in shaping students' minds away from what their human senses tell them and toward what they are told to believe (Salingaros 2014). They publish collections labeled as "Essential Readings in Architectural Theory", which are then used to teach entire generations of architecture students. This particular deception consists of two tactics: (i) proclaiming ideology as "theory"; and (ii) presenting the views of trendy contemporary architects and ideologues, with just one or two honest authors thrown in. This token gesture of inclusion is essential for misrepresenting the book as an unbiased selection, meant to educate students through broad exposure to different viewpoints. You will often hear architectural academics refer to this type of teaching as pluralism. The preponderance of text in such books, however, is self-serving and/or irrelevant. The early, "historical" section is oftentimes limited to the Bauhaus authors - nothing before that; little or nothing outside the closed confines of the industrial aesthetic; little or nothing about the vast building heritage of humankind.

\section{Building allegiance to an ideology}

Turning to an analogy from history and politics helps to better understand this phenomenon. The removal of inherited architectural knowledge (i.e. the history of architecture prior to the industrial revolution) also removes the conditions for loyalty to the discipline. There is nothing left to be loyal to - other than individuals (i.e. starchitects) and an ideology - and thus the door opens wide for opportunism and systemic corruption. Abusing the democratic process, a small elite gained power, confined rewards and privileges to its own members, and set up a framework (or commandeered an existing one) to protect its power base. Mechanisms for accountability were then diligently abolished. Loyalty is no longer towards the discipline, but only towards the controlling elite.

A larger entity to which people owe true loyalty is always defined by some solidly-established historical ideals. In the cases where those ideals have evolved from the ground up, the situation is humanly healthy. Those foundations lend systemic stability, which in turn permits disagreements, innovation, and debate while preserving the sanctity of the discipline itself. Any loyalty to an elite, self-assumed valuing system, however, is ill-founded and delusional. Dissent is not tolerated, breeding groupthink.

Collective research into the dimensions of human perception and neuro-connectivity has recently related the most immediate measures of architecture and design to human experience (Mehaffy, Salingaros 2011). Perceptual (i.e. neuro-physiological) engagement with the built environment defines what it is to be human, and allows us to operate in the physical world that surrounds us. From research in neuroscience, Evidence-Based Design, and Biophilia, etc., we have been able to clearly establish intelligence-based criteria for architecture. By its very nature, adaptive design is human in every dimension and is thus overtly antithetical to Modern design (Salingaros, Masden 2010). 
However, to our dismay, but not to our surprise, we are now witnessing what appear to be the dubious and concerted efforts of Modern architects to co-opt our research and work to further their own ideals.

Cunning members of the current "architectural establishment" realize that a major new market is developing around Pattern Language Design, EvidenceBased Design, Biophilic Design, and Intelligence-Based Design, and wish to get in on the ground floor and establish yet again another monopoly (i.e. a continuation of the old modernist monopoly). Those individuals are beginning to embrace our vocabulary and ideas, but only to subvert them so as to bolster their own heroes and ideology. Others shamelessly appropriate our ideas and those of our colleagues as their own, and use them in self-promotion. Modern architectural academics now lecture on mathematics and the new sciences applied to architecture: on algorithmic design, adaptivity and sustainability, nature and the human dimension, the sacred aspects of built form, etc. Such efforts are dishonest when judged by their concluding theme, which is to promote the same set of nihilistic architectural heroes. Appropriating the ideas of an intelligence-based design in order to twist them to opposite ends is simply an exercise in dishonesty and deception.

Even allowing for temperamental differences between artists and scientists (and treating architects as artists, which is the way they prefer it), the behavior of some of the Western World's key architectural figures tends to be rather sordid. Their lives and actions would appear to be marked by dishonesty and a lack of professional ethics and personal morality. No comparable behavior is to be found among, say, famous doctors throughout recent history. Famous architects court unsavory powers and regimes in search for commissions, apparently not bothered by any moral conscience. By buying into the displacement of thousands of families, in the name of their architectural ambitions, they are no different than the regimes that initiate such work. Worse of all, such historical facts are suppressed by architectural academia, which is complicit in covering up the ugly deeds of its famous names. By presenting these individuals as models, architectural academics have propagated a great lie onto their students and throughout the world.

\section{Conclusion: an honest architecture for people}

Contemporary architecture is at best an esoteric language, framed within a self-perpetuating argument that is rolled into an ideology, which sits above reason and rational purpose. At the heart of its argument is the appropriation of all ideas and information through a subversive aesthetic paradigm. For architecture in all its forms (from mere shed to great cathedral) to truly sustain humanity, it must be fundamentally based on structural principles found throughout the physical universe. It must also be supplemented with a deep understanding of what it is to be human: of human needs, activities, and perceptual (i.e. neuro-physiological) mechanisms. Students should know that while contemporary architects continue to fool themselves into believing that aesthetics or ideology can substitute for these requirements, engineers and other construction professionals are bypassing this ineffectual architectural philosophy. Non-architectural construction and design firms are capitalizing on the architectural elite's inability to work through realistic problems, leaving architects with less and less work to do. Architectural institutions, like the modern accreditation board, are beginning to voice concern about the marginalization of the profession due to these modern design practices.

As we structure a new model for the future, it is important that we set forth on the work-to-be-done with a newfound (or rediscovered) paradigm. This paradigm reveals a greater concern for the workings of the human mind than the formal ordering systems the twentieth century would allow. Beyond the party line of the tabula rasa, this new approach seeks to leave in place those elements and structures that imbue the built environment with a morphology that respects both time and space, both history and phenomenology. If indeed the profession develops into a new type of practice, it will sponsor forms of design that spring from existing conditions and traditions to render evergreater expressions in the work of multi-cultural world architects and urbanists.

The future opens up exciting possibilities for training a new generation of architecture students beyond the conditioning of modernist architectural systems. We are calling for nothing less than a fundamental change to the discipline's basis. We do not expect that the changes we are suggesting will be immediately embraced and applied unilaterally throughout the academic and professional institutions of architecture around the world. But we hope that those among us who have the passion, courage, and vision to see a better way will begin to reconstruct the study and practice of architecture. Utilizing an intelligence-based form of design to create a new world not only offers a truly human dimension to the built environment; it also folds together and inherently validates all other cultural forms, traditions, and sensibilities. We need only look around us to see that the dominating iconic forms of the reigning model, by contrast, serve solely to disregard all architectures and cultures of the world except their own. 


\section{Acknowledgment}

This article includes reworked material from "Intelligence Based Design", ArchNet-IJAR 2 (1), March 2008: 176-180, republished online in the New English Review, September 2013.

\section{References}

Mehaffy, M. W.; Salingaros, N. A. 2002. Geometrical fundamentalism, Plan Net Online Architectural Resources (no longer online), reprinted as Chapter 9 in N. A. Salingaros, 2006, 2014. A theory of architecture. Portland, Oregon, USA: Sustasis Press and Kathmandu, Nepal: Vajra Books. Available from Internet: https://www.academia. edu/5074196/Geometrical_fundamentalism

Mehaffy, M. W.; Salingaros, N. A. 2011. Architectural myopia, Shareable, October, also titled: The architect has no clothes, On the Commons Magazine, October [online], [cited August 2014]. Available from Internet: http://www.shareable.net/ blog/architectural-myopia-designing-for-industry-notpeople

Salingaros, N. A. 2002. Twentieth-century architecture as a cult, INTBAU Essays 1(3) (November). Reprinted as Chapter 7 of N. A. Salingaros 2014. Anti-architecture and deconstruction. 4th ed. Portland, Oregon, USA: Sustasis Press and Kathmandu, Nepal: Vajra Books [online], [cited August 2014]. Available from Internet: http://www.intbau. org/archive/essay3.htm

Salingaros, N. A. 2014. Cognitive dissonance and non-adaptive architecture, Doxa 11: 100-117. Istanbul: Norgunk Publishing House. Republication of an online article from P2P FOUNDATION, February 2011 and reprinted in INTBAU Essays, March 2011 [online], [cited August 2014]. Available from Internet: http://permaculturenews. org/2011/02/09/cognitive-dissonance-and-non-adaptivearchitecture-seven-tactics-for-denying-the-truth/

Salingaros, N. A.; Masden, K. G. 2010. Teaching design at the limits of architecture, IJAR - International Journal of Architectural Research 4(2, 3): 19-31 [online], [cited August 2014]. Available from Internet: http://zeta.math. utsa.edu/ yxk833/teachingdesignatthelimits.pdf

\section{KENNETH G. MASDEN II}

Department of Education, State of Hawaii, Honolulu, 96821 Hawaii, USA.

Kenneth G. Masden II AIA, is an NCARB certified architect with a BArch from the University of Kentucky and an MArch from Yale University - where he studied with Léon Krier, Vincent Scully, Fred Koetter, and Andrés Duany. He has extensive experience with large-scale planning projects including base relocation and land reclamation projects totaling over $\$ 4$ billion for the U.S. Government, on which he has worked as project architect, environmental engineer, planner, and program manager, in Japan, Germany, Spain, Italy, and the United States. From 2001-2010 he was an Assistant/Associate Professor of Architecture and Urban Design at the University of Texas at San Antonio. Before beginning his academic career he worked with Peter Eisenman. Currently the Director of Planning and Development for the Hawaii Department of Education, he manages a capital improvement budget of $\$ 300$ million/year for the $7^{\text {th }}$ largest public school system in the nation.

\section{NIKOS A. SALINGAROS}

Department of Mathematics, University of Texas at San Antonio, San Antonio, 78249 Texas, USA.

E-mail: salingar@gmail.com

Nikos A. Salingaros (Dr) is the author of six monographs on architectural and urban design translated into six languages, and over 150 scientific papers. Dr Salingaros is a leader in developing the disciplines of Biophilia, Complexity, and Peer-toPeer Urbanism. In Planetizen's 2009 survey, he was ranked $11^{\text {th }}$ among "The Top Urban Thinkers of All Time", and was selected by UTNE Reader in 2008 as one of the " 50 Visionaries who are Changing Your World". His most recent books are: Twelve Lectures on Architecture: Algorithmic Sustainable Design, 2010, and Unified Architectural Theory: Form, Language, Complexity. A Companion to Christopher Alexander's 'The Phenomenon Of Life, The Nature of Order, Book 1', 2013. He is Professor of Mathematics at the University of Texas at San Antonio, and is associated with the architecture faculties of several institutions around the world. 